\title{
Development and Characterization of a Potent Tumor Necrosis Factor-Alpha-Blocking Agent
}

\author{
Aida Jameei, ${ }^{1}$ Deepesh Nagarajan,, Mohsen Sarikhani, ${ }^{2,3}$ Nagasuma Chandra, ${ }^{1}$ and Anjali A. Karande ${ }^{1}$
}

Tumor necrosis factor- $\alpha(\mathrm{TNF} \alpha)$, one of the major proinflammatory cytokines, plays a key role in an effective immune response. However, the chronic presence of $\mathrm{TNF} \alpha$ can lead to several inflammatory disorders, such as rheumatoid arthritis, psoriasis, Crohn's disease, etc. Inhibition of TNF $\alpha$ by pharmacological inhibitors or antibodies has proven to be effective in palliative treatment to some extent. The aim of this study was to develop an anti-TNF $\alpha$ antibody, which may be used as a therapeutic option to inhibit TNF $\alpha$-mediated cytotoxicity. We characterized several hybridoma clones secreting monoclonal antibodies (mAbs) to human-TNF $\alpha$. Four mAbs rescued L929 fibroblast cells from $\mathrm{TNF} \alpha$-triggered cell death and one of these, namely $\mathrm{C} 8$, was found to have the highest affinity. To gain insights into the mechanism by which mAb C8 inhibits human TNF $\alpha$-mediated toxicity, the epitope corresponding to the $\mathrm{mAb}$ was delineated. The antigenic determinant was found to comprise of the stretch of amino acids 99-120, of which, 102-104 (glutamine, arginine, glutamic acid) form the core epitope. The observation was supported by bioinformatics analyses of an antigen/antibody complex model. In addition, the binding affinity of $\mathrm{mAb}$ $\mathrm{C} 8$ to TNF $\propto$ was found to be comparable with that of infliximab, which is a commercially available anti-TNF $\alpha \mathrm{mAb}$.

Keywords: monoclonal antibodies, TNF $\alpha$, inflammation

\section{Introduction}

$\mathbf{T}$ UMOR NECROSIS FACTOR (TNF) IS A proinflammatory cytokine having pleiotropic effects on immune cells and plays an indispensable role in inflammation, cell differentiation, cell proliferation, apoptosis, and cell metabolism. ${ }^{(1,2)}$

There are two types of TNF, tumor necrosis factor- $\alpha$ (TNF $\alpha)$ and tumor necrosis factor- $\beta$ (TNF $\beta$ ), both of which are cytotoxic. ${ }^{(3,4)}$ They are sequentially and structurally related and compete with each other for binding to their receptors. ${ }^{(5)}$ Soluble $\mathrm{TNF} \alpha$ exerts a broad range of biological activities on interaction with two specific receptors, TNF $\alpha$ receptor-type 1 (TNFR1 or p55) and TNF $\alpha$ receptor-type 2 (TNFR2 or p75). TNFR1, expressed on almost all cell types, plays a major role in triggering the $\mathrm{TNF} \alpha$ signaling pathways. TNFR2 expression on the other hand is mostly limited to the cells of the immune system, nerve cells, and endothelial cells under normal physiological conditions. ${ }^{(6-8)}$ Upon binding to receptors, $\mathrm{TNF} \alpha$ promotes a series of intracellular signaling cascades, such as, activation of transcription factor $\mathrm{NF \kappa B}$, p38 mitogen-activated protein kinase (p38MAPK), and c-Jun N-terminal kinase (JNK) extracellular signal-regulated kinase. ${ }^{(8,9)}$

Although TNF $\alpha$ plays an essential role in an effective immune response, its unrestricted production may lead to several inflammatory disorders. Inhibition of TNF $\alpha$ by pharmacolog- ical agents has proven to be effective in palliative treatment. $(10,11)$

In the study described in this article, we developed an antihuman TNF $\alpha$ (hTNF $\alpha$ ) monoclonal antibody (mAb), namely $\mathrm{C} 8$, which can neutralize human-TNF $\alpha$ activity. Furthermore, using truncation and mutation analysis, we mapped the TNF $\alpha$-binding sites of the mAb, which was supported by docking studies using sequenced variable regions of heavy and light chain of the antibody.

A study of mAb C8 and infliximab (a commercialized anti$\mathrm{TNF} \alpha$ antibody), demonstrated that both antibodies have comparable affinities as well as $\mathrm{TNF} \alpha$-neutralizing efficiency.

\section{Methods}

\section{Animal and cell lines}

All the animal experiments were reviewed and approved by the Institutional Animal Ethics Committee (IAEC) of the Indian Institute of Science, CAF/Ethics/184/2010 dated June 16, 2010. L929 mouse fibroblast cells were maintained as monolayer cultures in Dulbecco's modified Eagle's medium (DMEM) and passaged every 2-3 days using $0.25 \%$ trypsin-EDTA. Hybridoma cells were cultured in Iscove's modified Dulbecco's medium (IMDM). Both media were supplemented with $10 \%$ fetal bovine serum (FBS), 1 mM GlutaMAX (Gibco), and

Departments of ${ }^{1}$ Biochemistry and ${ }^{2}$ Microbiology and Cell Biology, Indian Institute of Science (IISc), Bengaluru, India.

${ }^{3}$ Stem Cell and Regenerative Biology Department, University of Harvard, Cambridge, Massachusetts. 
antibiotics. IMDM was supplemented also with $50 \mu \mathrm{M} \beta$ mercaptoethanol. All cultures were maintained at $37^{\circ} \mathrm{C}$ in a humidified incubator with $5 \% \mathrm{CO}_{2}$.

\section{Expression and purification of His-tagged human-TNF $\alpha$ and mouse-TNF $\alpha$}

Escherichia coli BL21 (DE3) strain cells were transformed with the $\mathrm{pET} 15 \mathrm{~b}$ vector containing the human-TNF $\alpha$ gene and $\mathrm{pET} 28 \mathrm{a}$ vector containing the mouse-TNF $\alpha$ gene. Then, cells were induced with $1 \mathrm{mM}$ IPTG and were incubated at $30^{\circ} \mathrm{C}$ for 8 hours in an incubator shaker at $200 \mathrm{rpm}$ for the expression of each respective protein; the cells were harvested by centrifugation at $6000 \mathrm{rpm}$ for 20 minutes at $4^{\circ} \mathrm{C}$. The cell pellet obtained was resuspended with $50 \mathrm{mM}$ Tris$\mathrm{HCl}, \mathrm{pH} 8.0$ containing $150 \mathrm{mM} \mathrm{NaCl}$ (TBS), sonicated (sonication conditions: $4^{\circ} \mathrm{C}$, ampt $30 \%, 30$ minutes), and the soluble proteins were separated by centrifugation at $13,000 \mathrm{rpm}$ for 30 minutes at $4^{\circ} \mathrm{C}$. The supernatant (soluble protein) was loaded on the Ni-NTA column. Unbound proteins were washed away with TBS containing $30 \mathrm{mM}$ imidazole and the bound protein was eluted with $300 \mathrm{mM}$ imidazole in TBS. After elution, the protein was dialyzed against phosphate-buffered saline (PBS; $50 \mathrm{mM}$ phosphate buffer $\mathrm{pH}, 7.4$, containing $150 \mathrm{mM} \mathrm{NaCl}$ ). The concentration of proteins was estimated using Bradford method.

\section{Generation of mAbs against human-TNF $\alpha$}

Eight-week-old female BALB/c mice were immunized by subcutaneous injection with $5 \mu \mathrm{g}$ of human-TNF $\alpha$ protein in phosphate-buffered saline (PBS) emulsified with Freund's complete adjuvant and boosted twice with $5 \mu \mathrm{g}$ of the same antigen in Freund's incomplete adjuvant at 21 days interval. The animals were rested for a month. Three days before sacrificing, the mice were administrated intraperitoneally with $5 \mu \mathrm{g}$ of antigen in PBS. The splenocytes were collected and fused with mouse myeloma cells SP2/0 (ratio 5:1) using PEG 4000 (Merck, Rahway, NJ). The fused cells were plated in IMDM supplemented with HAT (10 mM hypoxanthine, $40 \mu \mathrm{M}$ aminopterin, and $1.6 \mathrm{mM}$ thymidine), $20 \%$ (v/v) FBS, and $50 \mu \mathrm{M}$ Mercaptoethanol. They were examined for secretion of anti-TNF $\alpha$-specific antibodies using enzyme-linked immunosorbent assay (ELISA) after 10 days. The positive clones were subcloned to monoclonality by limiting the dilution method. mAbs were purified by protein A (Sigma-Aldrich, St. Louis MO).

\section{Enzyme-linked immunosorbent assay}

ELISA plates were coated with protein in $100 \mu \mathrm{L}$ PBS (50 $\mathrm{mM}$ phosphate buffer $\mathrm{pH}, 7.4$, containing $150 \mathrm{mM} \mathrm{NaCl}$ ), overnight at room temperature (RT). After blocking the unoccupied sites of the wells with $0.5 \%$ gelatin in PBS for 1 hour at RT, hybridoma culture supernatants or purified antibodies were added and incubated for 2 hours. Plates were washed with PBST ( $\mathrm{T}=$ Tween 20 , at $0.05 \%$ ) followed by PBS and incubated with $100 \mu \mathrm{L}$ of secondary antibody conjugated to horse radish peroxidase (HRP) for 45 minutes. After washing the plates, $100 \mu \mathrm{L}$ of substrate $\left(0.03 \% \mathrm{H}_{2} \mathrm{O}_{2}\right.$ in citrate phosphate buffer, $\mathrm{pH} 5.5$, and the chromogen $3,3^{\prime}, 5$, $5^{\prime}$-tetra methyl benzidine $\left.[60 \mu \mathrm{g} / \mathrm{mL}]\right)$ was added. The reac- tion was stopped with $50 \mu \mathrm{L}$ of $1 \mathrm{M} \mathrm{H}_{2} \mathrm{SO}_{4}$ and absorbance was measured at $450 \mathrm{~nm}$ using an ELISA microplate reader.

To determine comparative affinities of the mAbs, ELISA was performed as above, but after the incubation with the mAbs, ammonium thiocyanate $\left(\mathrm{NH}_{4} \mathrm{SCN}\right)$ was added at varying concentrations $(0.5,1.0,2.0,3.0,4.0$, and $6.0 \mathrm{M})$ in $0.1 \mathrm{M}$ sodium phosphate buffer, $\mathrm{pH}$ 6.0. The plates were incubated for 15 minutes at RT before washing with PBS, followed by blocking with $0.5 \%$ bovine serum albumin in PBS for 1 hour at RT, before addition of the secondary antibody conjugate. The rest of the procedure followed was as mentioned above.

For obtaining antigen and antibody dilution curves, four concentrations $(500,250,125,62.5 \mathrm{ng} /$ well in $100 \mu \mathrm{L}$ PBS) of hTNF $\alpha$ were coated in ELISA plate, blocked with $0.5 \%$ gelatin in PBS, and $100 \mu \mathrm{L}$ serially double diluted hybridoma culture supernatant was added ranging from undiluted to 1:1024 and incubated for 2 hours at RT. The remaining steps were carried out in the same way as mentioned above.

For Inhibition ELISA, $500 \mathrm{ng}$ antigen/well was coated in ELISA plate overnight at RT. After blocking the plates with $0.5 \%$ gelatin in PBS for 1 hour at RT, varying concentrations of the antigen $(5 \mu \mathrm{g}$ serially double diluted to $0.0097 \mu \mathrm{g})$ was added in $50 \mu \mathrm{L}$, followed immediately with $50 \mu \mathrm{L}$ of appropriately diluted (exhibiting a binding of $\sim 85 \%$ of the Bmax) anti-TNF $\alpha$ antibodies and incubated for 2 hours at RT. The remaining steps were carried out in the same way as mentioned above.

\section{Western blot analysis of $m A b C 8$}

HumanTNF $\alpha$ or its fragments, $1 \mu \mathrm{g}$ each were electrophoresed on $12.5 \%$ polyacrylamide gel under reducing conditions and transferred to nitrocellulose membrane using a semidry electrotransfer apparatus, at $125 \mathrm{~mA}$. The membrane was incubated in a blocking solution $(5 \%$ skimmed milk in PBS) for 2 hours or overnight followed by incubation with the $\mathrm{mAb}$ for 2 hours. The membrane was washed with PBST and incubated with the secondary antibody (rabbit $\alpha$-mouse IgHRP) for 45 minutes and developed using the ECL Kit (Millipore).

L929 cells were incubated with TNF $\alpha$ for 30 minutes, then washed with cold PBS 3 times, followed by suspension in lysis buffer $(20 \mathrm{mM}$ Tris $\mathrm{pH} 7.5,150 \mathrm{mM} \mathrm{NaCl}, 1 \%$ Triton $\times 100,1 \mathrm{mM}$ EDTA, $1 \mathrm{mM}$ EGTA, NaVo3, Sodium Pyrophosphate, and Protease Inhibitors). The mixture was vortexed and centrifuged and the protein concentration of the supernatant was estimated. Equal amounts of each protein sample were mixed with Laemmli Buffer $(2 \times$, Bio-Rad $)$, heated for 5 minutes at $95^{\circ} \mathrm{C}$ and resolved by sodium dodecyl sulfate/polyacrylamide gel electrophoresis (SDS-PAGE) followed by overnight transfer to a PVDF membrane (Cat\# 10600023 ; GE) at $25 \mathrm{~V}$ at $4^{\circ} \mathrm{C}$. The membrane was blocked with $5 \%$ nonfat dried milk in TBST buffer $(25 \mathrm{mM}$ Tris- $\mathrm{HCl}$, $\mathrm{pH} 7.5,150 \mathrm{mM} \mathrm{NaCl}, 0.05 \%$ Tween 20). For detection of proteins, blots were incubated with their respective antibodies (anti -JNK, -p-JNK, $-\beta$ actin) at $4^{\circ} \mathrm{C}$ overnight. After washing three times with TBST buffer, peroxidase-conjugated secondary antibody (1:10,000; Santa Cruz) was added and incubated at RT for 1 hour. Signals were detected using chemiluminescence substrate solution (Cat\# 34080; Thermo Fisher) and analyzed by a GE LAS4000 luminescent image analyzer (Fuji Photo Film). 
Table 1. List of Oligonucleotides Used for Generating the Deletion Constructs of hTNF $\alpha$

\begin{tabular}{llc}
\hline Primer name & \multicolumn{1}{c}{ Sequence $\left(5^{\prime} \rightarrow 3^{\prime}\right)$} & Restriction enzyme site \\
\hline F1 1-53 FP & TAACCGGGATCCCGGTCAGATCATCTTCTC & BamHI \\
F1 1-53 RP & TGCTTCCGCTCGAGTCACTCTGATGGCACCAC & XhoI \\
F2 26-131 FP & TAACCGGGATCCCGCTCCAGTGGCTGAAC & BamHI \\
F2 26-131 RP & TGCTTCCGCTCGAGTCATCGGTCACCCTTCTCC & XhoI \\
F3 96-157 FP & TAACCGGGATCCCGCCATCAAGAGCCCCTG & BamHI \\
F3 96-157 RP & TGCTTCCGCTCGAGTCACAGGGCAATGATC & XhoI \\
F2 core 54-93 FP & TAACCGGGATCCCG GTGGTGCCATCAGAG & Bam HI \\
F2 core 54-93 RP & TGCTTCCGCTCGAGTCACAGGGGCTCTTGATGG & XamHI \\
F2-F1 72-131 FP & TAACCGGGATCCCGCTCCTCACCCACACC & BamHI \\
R1 72-107 FP & CCGGGATCCCGCTCCTCACCCACACC & XhoI \\
R1 72-107 RP & CCGCTCGAGTCACTCTGGGGTCTCCCTCTGG & BamHI \\
R2 99-131 FP & CCGGGATCCCCtgCCAGAGGGAGACCC & XhoI \\
R2 99-131 RP & CCGCTCGAGTCATCGGTCACCCTTCTCC & BamHI \\
R3 85-120 FP & CCGGGATCCCCTACCAGACCAGGGTC & XhoI \\
R3 85-120 RP & CCGCTCGAGTCACAGATAGATGGGCTCATAC & \\
\hline
\end{tabular}

FP, forward primer; hTNF $\alpha$, human tumor necrosis factor- $\alpha$; RP, reverse primer.

\section{MTT assay}

Viability of cells was checked using 3-(4, 5-dimethylthiazol2-yl)-2, 5-diphenyltetrazolium bromide (MTT) assay. For the assay, L929 fibroblast cells were plated in 48-well flat bottom tissue culture plate at 10,000 cells/well in $200 \mu \mathrm{L}$ DMEM supplemented with $10 \%$ FBS. Cells were allowed to attach overnight and then incubated with different concentrations of $\mathrm{hTNF} \alpha$. Actinomycin-D $(2 \mu \mathrm{g} / \mathrm{mL})$ was used as positive control. After 48 hours of incubation, $20 \mu \mathrm{L}$ of MTT solution $(5 \mathrm{mg} / \mathrm{mL}$ in PBS) was added per well, incubated for 4 hours at $37^{\circ} \mathrm{C}$ in $\mathrm{CO}_{2}$ incubator. Formazan crystals formed as a result were dissolved with $100 \mu \mathrm{L}$ of DMSO and transferred to a 96well culture plate and optical density was measured in a microplate reader, at $570 \mathrm{~nm}$.
Cloning of mutant constructs of hTNF $\alpha$ gene

Deletion constructs of the $h T N F \alpha$ gene were cloned in pGEX5X2 vector between BamHI and XhoI restriction enzyme sites at the $5^{\prime}$ and $3^{\prime}$ end, respectively. All clones carried an N-terminal glutathione S-transferase (GST)-tag and were amplified employing the primers listed in Table 1.

The polymerase chain reaction (PCR) cycle used for the amplification procedure was as follows: initial denaturation $-94^{\circ} \mathrm{C}, 5$ minutes; denaturation $-94^{\circ} \mathrm{C}, 1$ minute; annealing $-55^{\circ} \mathrm{C}, 45$ seconds; extension $-72^{\circ} \mathrm{C}, 1$ minute; final extension $-72^{\circ} \mathrm{C}, 10$ minutes. The denaturation, annealing, and extension steps were carried out for 30 cycles. The hTNF $\alpha$ cloned in pET15b was used as the template and Deep Vent polymerase was used for amplification of DNA in the PCRs.

Table 2. List of Oligonucleotides Used for Generating the Site-Directed Mutants of hTNF $\alpha$

\begin{tabular}{ll}
\hline Primer name & \multicolumn{1}{c}{ Sequence $\left(5^{\prime} \rightarrow 3^{\prime}\right)$} \\
\hline S71deletion FP & CCAAGGCTGCCCCGACTACGTGCTCC \\
S71deletion RP & GGAGCACGTAGTCGGGGCAGCCTTGG \\
T72D FP & CAAGGCTGCCCCTCCGACCATGTGCTCCTC \\
T72D RP & GAGGAGCACATGGTCGGAGGGGCAGCCTTG \\
H73Y FP & GGCTGCCCCTCCACCTACGTGCTCCTCAC \\
H73Y RP & GTGAGGAGCACGTAGGTGGAGGGGCAGCC \\
TH72,73DY FP & GGCTGCCCCTCCGACTACGTGCTCCTCAC \\
TH72,73DY RP & GTGAGGAGCACGTAGTCGGAGGGGCAGCC \\
S71 deletion T72D P & CCAAGGCTGCCCCGACCATGTGCTCC \\
S71 deletion RP & GGAGCACATGGTCGGGGCAGCCTTGG \\
S71 deletion H73Y P & CCAAGGCTGCCCCGACCATGTGCTCC \\
S71 deletion H73Y P & GGAGCACGTAGGTGGGGCAGCCTTGG \\
T89E FP & CATCGCCGTCTCCTACCAGGAGAGGGTCAACCTCCTCTCTG \\
T89E RP & CAGAGAGGAGGTTGACCCTCTCCTGGTAGGAGACGGCGATG \\
Q102P FP & GGGTCTCCCTCGGGCAGGGGCTC \\
Q102P RP & GAGCCCCTGCCCGAGGGAGACCC \\
R103K FP & GGGGTCTCCTTCTGGCAGGGGCTCTTG \\
R103K RP & CAAGAGCCCCTGCCAGAAGGAGACCCC \\
E104D FP & CTCTGGGGTATCCCTCTGGCAGGGGCT \\
E104D RP & AGCCCCTGCCAGAGGGATACCCCAGAG \\
RE103,104KD FP & CAAGAGCCCCTGCCAGAAGGATACCCCAGAG \\
RE103,104KD RP & CTCTGGGGTATCCTTCTGGCAGGGGCTCTTG \\
R131Q FP & GAGAAGGGTGACCAATGACTCGAGCGG \\
R131Q RP & CCGCTCGAGTCATTGGTCACCCTTCTC \\
\hline
\end{tabular}


TABle 3. List of Oligonucleotides Used FOR Generating Monoclonal Antibody C8 Variable Regions of Heavy and Light

\begin{tabular}{lc}
\hline Primer name & \multicolumn{1}{c}{ Sequence $\left(5^{\prime} \rightarrow 3^{\prime}\right)$} \\
\hline VH FP & TGAGGAGACGGTGACCGTGGTCC \\
VH RP & CTTGGCCCCA \\
VL FP & GTTAGATACTCTCCAGGAGTCAGG \\
VL RP & GACATTCAGCTGACCCAGTCTCCA
\end{tabular}

$\mathrm{VH}$, variable regions of heavy; VL, variable regions of light.

The clones obtained were screened by digestion with restriction enzymes and confirmed by DNA sequencing.

Site-directed mutant genes were generated by QuikChange Primer Design method. ${ }^{(12)}$ Sense and antisense primers carried the desired site-specific mutation along with a specific restriction enzyme site. The plasmid carrying the wild-type $h T N F \propto$ gene construct was amplified by PCR. The amplified product was subjected to $D p n I$ digestion to digest the methylated plasmid template and E. coli DH5 $\alpha$ cells were transformed with the plasmid.

The hTNF $\alpha$ F2 mutant clones, T72 to D; H73 to Y; T89 to E; S71deletion; TH72,73 DY; Q102 to P; R103 to K; E104 to D; R103E104 to KD; R131 to Q; S71 deletion + T 72 to D; S 71 deletion + H73 to Y; and Q102R103E104 to proline, lysine, aspartic acid (PKD) were obtained by QuikChange Primer Design method. Phusion High-Fidelity DNA Polymerase was used for carrying out PCRs. In a PCR cycle, initial denaturation was carried out at $98^{\circ} \mathrm{C}$ for 2 minutes followed by 25 cycles of denaturation at $98^{\circ} \mathrm{C}$ for 1 minute, annealing for 1 minute (at the temperature specified for each clone in Table 2), and extension at $72^{\circ} \mathrm{C}$ for 6 minutes. The final extension for end filling was carried out at $72^{\circ} \mathrm{C}$ for 10 minutes (For first 4 cycles, we have prepared reactions with forward or reverse primers separately and then pooled together for another 21 cycles).

All site-directed mutant DNA fragments obtained were cloned in pGEX5X2 vector between BamHI and XhoI restriction enzyme sites. The recombinant plasmids were isolated. The sequence of the clones obtained was verified by sequencing to confirm the presence of the desired mutations. All clones carried an N-terminal GST-tag and were amplified employing the primers listed in Table 2 .

cDNA was prepared from total RNA isolated from $\mathrm{mAb}$ C8 hybridoma cells using oligo (dT) primers. The variable regions of the heavy (VH) and light chain (VL) were amplified by PCR using the cDNA as template and the respective universal primers listed in Table 3 . The VH and VL DNA fragments ( $\sim 300 \mathrm{bp}$ ) were generated using Deep Vent polymerase, cloned into the pGEMT vector system and screened by digestion with the restriction enzymes NcoI and NdeI. The DNA was sequenced.

\section{Expression and purification of $h T N F \alpha$ recombinant proteins}

All recombinant hTNF $\alpha$ overlapping truncated and mutant forms of hTNF $\alpha \mathrm{F} 2$ constructs in pGEX5X2 vector have an N-terminal GST-tag. E. coli BL21 (DE3) cells were transformed with each plasmid and were induced to express re- spective protein with $1 \mathrm{mM}$ IPTG for hTNF $\alpha \mathrm{F} 1$ and $\mathrm{F} 3$ for 4 hours at $30^{\circ} \mathrm{C}$ and $0.1 \mathrm{mM}$ IPTG for hTNF $\alpha \mathrm{F} 2$ and F2-mutants for 14 hours at $20^{\circ} \mathrm{C}$ in an incubator shaker, at $200 \mathrm{rpm}$. The cells were harvested with centrifugation and the pellet obtained was resuspended and sonicated in lysis buffer ( $50 \mathrm{mM}$ Tris, $\mathrm{pH} 8,150 \mathrm{mM} \mathrm{NaCl}$, and $1 \mathrm{mM}$ PMSF) containing lysozyme for 20 minutes using 5 seconds On and Off pulses and then spun at $13,000 \mathrm{rpm}$ for 30 minutes at $4^{\circ} \mathrm{C}$. The supernatant was passed through a pre-equilibrated column (using wash buffer: $20 \mathrm{mM}$ Tris, pH 7.5, $150 \mathrm{mM} \mathrm{NaCl}$, and $0.1 \%$ Triton X-100), Unbound proteins were washed away with wash buffer and the GST-fusion protein was eluted with $10 \mathrm{mM}$ reduced glutathione in $50 \mathrm{mM}$ Tris, $\mathrm{pH}$ 8. After elution, the protein was dialyzed against PBS. The concentration of proteins was estimated using the Bradford method.

\section{Bioinformatics analysis}

To determine the amino acid sequence of the VH and VL chains of $\mathrm{mAb} \mathrm{C} 8$, the amino acid sequence derived from the obtained DNA sequences were utilized for hTNF $\alpha-\mathrm{C} 8$ docking study. hTNF $\alpha$ - mAb C8 modeling was performed using the SWISS-MODEL server ${ }^{(13)}$ and superposed onto PDB ID 4g3y using Mustang. ${ }^{(14)}$ All structural images were analyzed and visualized using the open-source PyMOL software. Local protein/protein docking and energy minimization for both wild type (WT) TNF-Ab as well as mutated TNF-Ab complexes was performed using Rosetta. ${ }^{(15)}$

\section{Results}

The $h T N F \alpha$ gene was cloned in a His-tag expression vector, expressed and purified using Ni-NTA affinity chromatography, and the expected protein size was seen in SDSPAGE gel stained with Coomassie Brilliant Blue. Mass spectrometry analysis confirmed the molecular size of the purified hTNF $\alpha$ (Supplementary Fig. S1A, B).

\section{Binding of anti-TNF $\alpha$ mAbs to TNF $\alpha$}

To screen the binding of the mAbs to hTNF $\alpha$, indirect ELISA was carried out. Thirteen clones were found to bind specifically to hTNF $\alpha$ (Supplementary Fig. S1C). In spite of more than $70 \%$ sequence identity between human and mouse $\mathrm{TNF} \alpha(\mathrm{mTNF} \alpha)$, only one out of the $13 \mathrm{mAbs}$, namely $\mathrm{C} 12$, bound also to mouse-TNF $\alpha$ (Supplementary Fig. S1D).

To identify high-affinity antibodies, different concentrations of immobilized hTNF $\alpha$ antigen were incubated with different dilutions of the anti-TNF $\alpha$ mAbs. While all the mAbs bound to $500 \mathrm{ng}$ h-TNF $\alpha$, except mAbs C8 and $\mathrm{C} 12$, none bound significantly to lower concentrations of the immobilized antigen. In case of the $\mathrm{mAb} \mathrm{C} 8$, there was no apparent difference in the binding of the $\mathrm{mAb}$ to even $\sim 60 \mathrm{ng}$ immobilized antigen (Fig. 1A).

If $\mathrm{mAbs}$ are to be used in therapy, they should bind to antigen in solution phase. Inhibition ELISA was therefore performed. As can be seen in Figure 1B, free antigen was able to compete out the binding of the mAbs to the immobilized antigen in a concentration-dependent manner in case of mAbs C1, C2, C7, and C8 (data not shown for the other mAbs). Therefore, the four mAbs were selected for further studies. Subclass isotyping studies revealed mAbs C1, C2, 

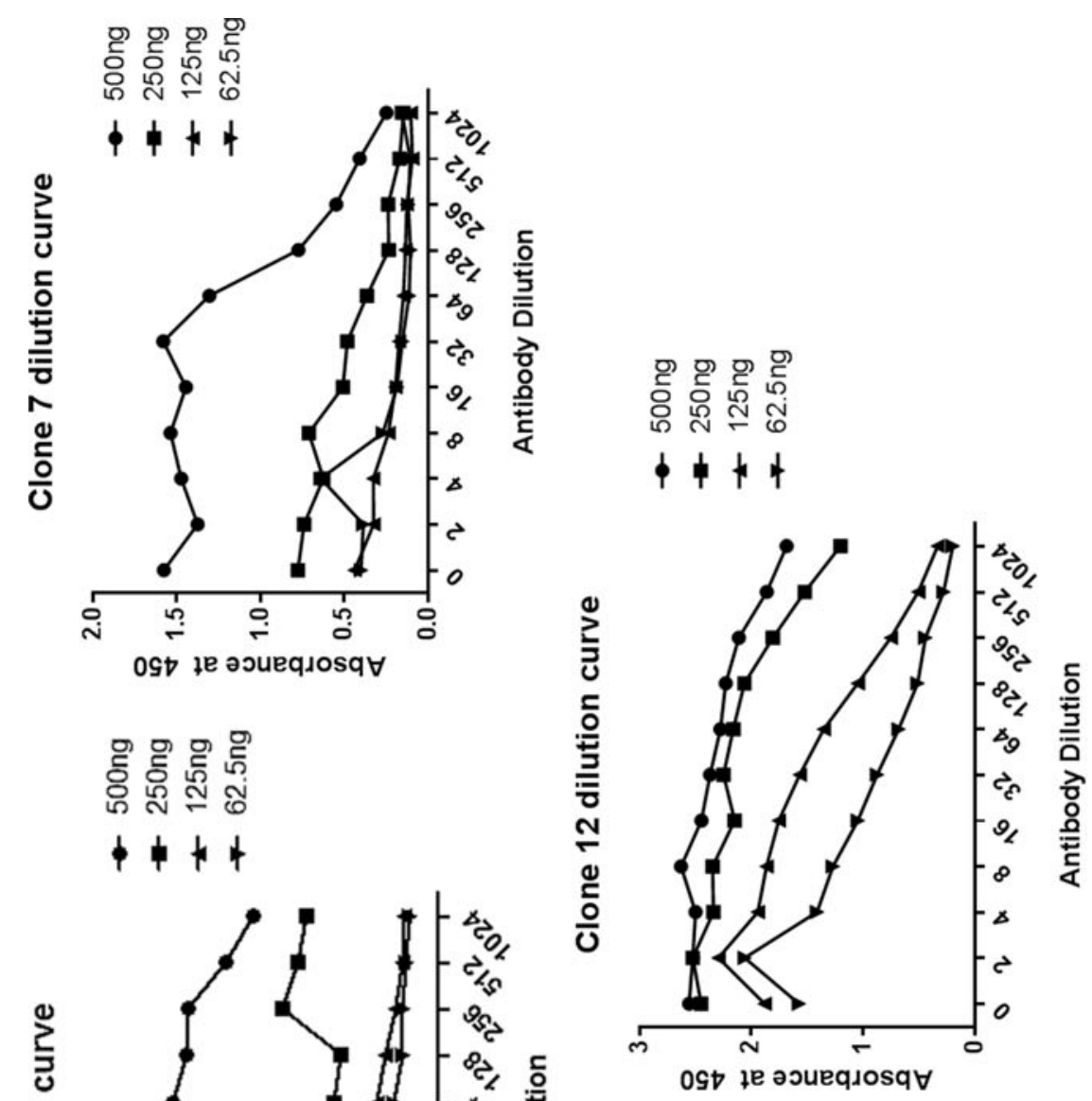

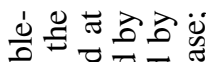

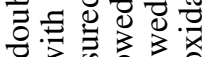

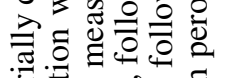

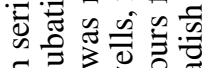

氙

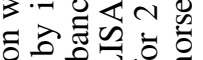

혛거엉

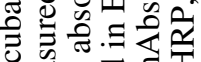

$\Xi \widetilde{\Phi} \Xi \Xi$

으윯

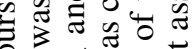

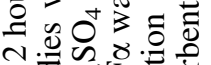

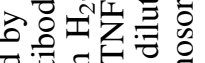

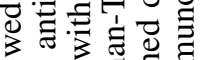
응 怔晶.引
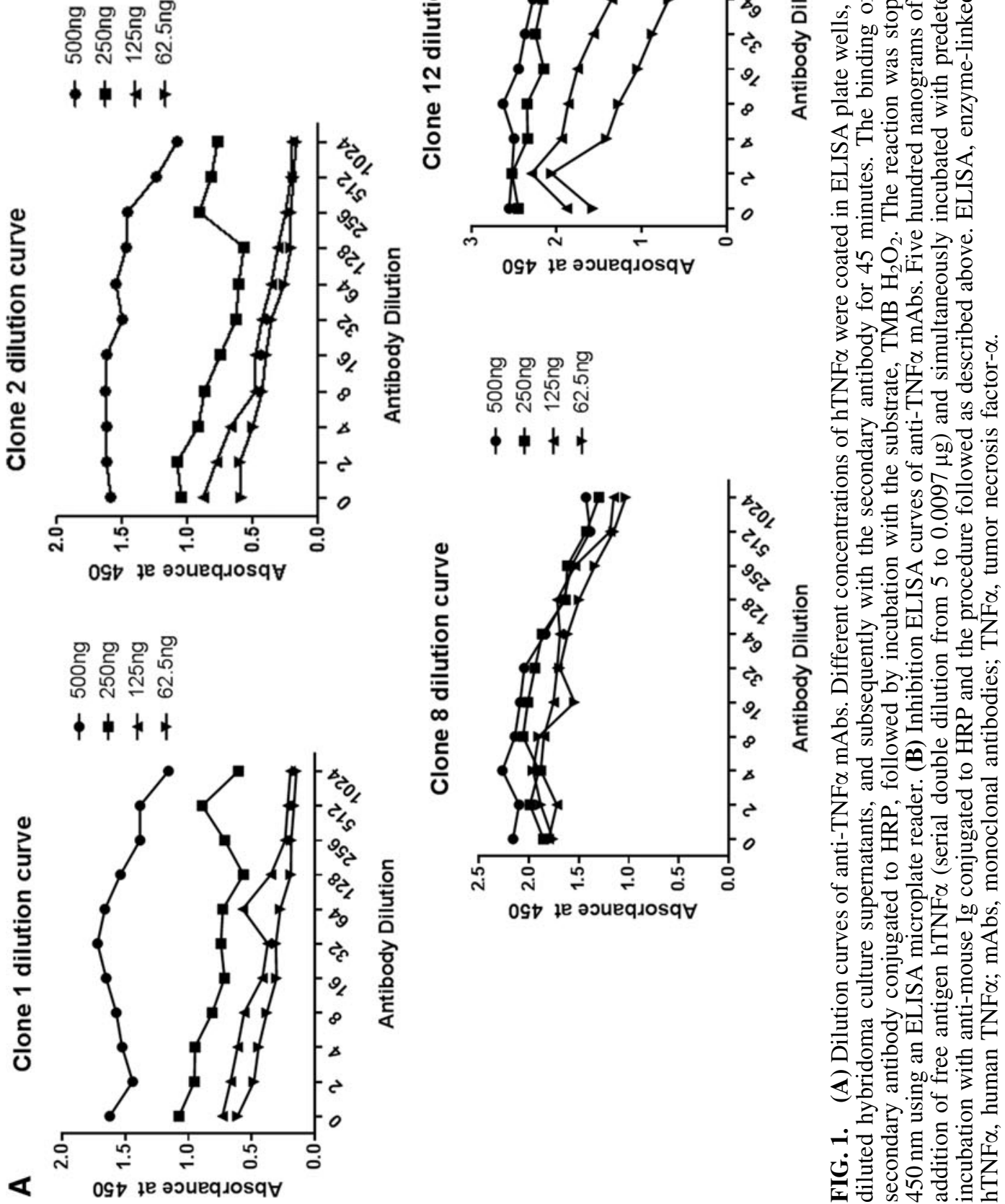
B Clone 1 Inhibition ELISA Assay

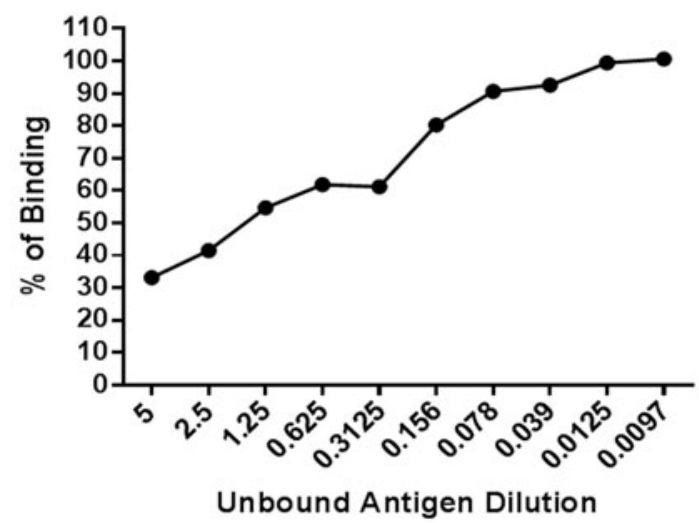

Clone 7 Inhibition Elisa Assay

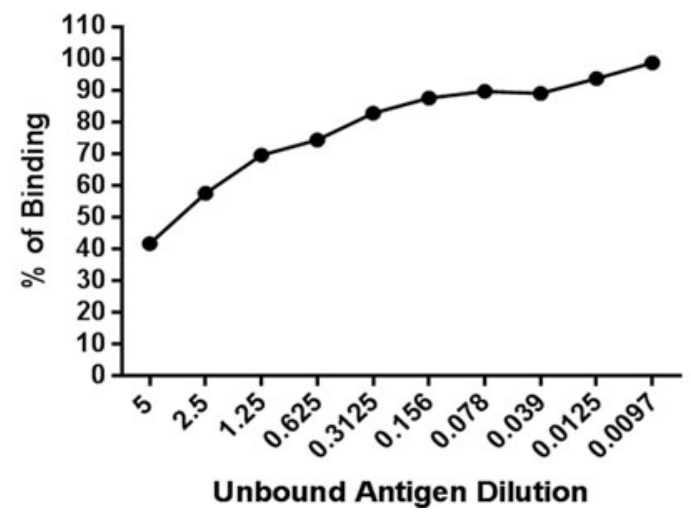

Clone 2 Inhibition Elisa Assay

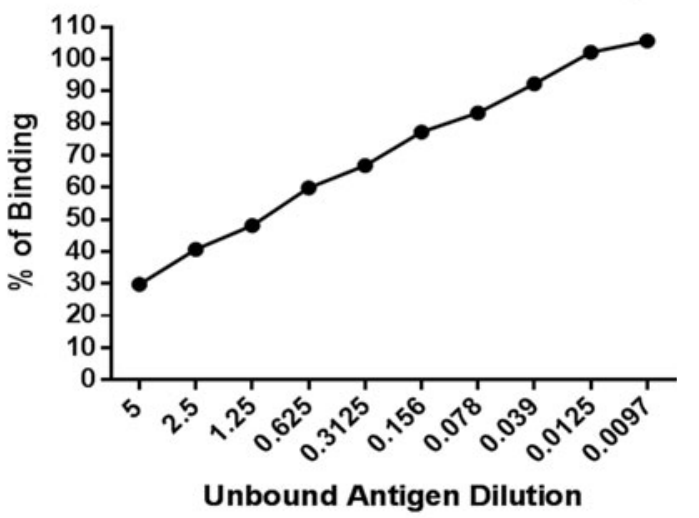

Clone 8 Inhibition Elisa Assay

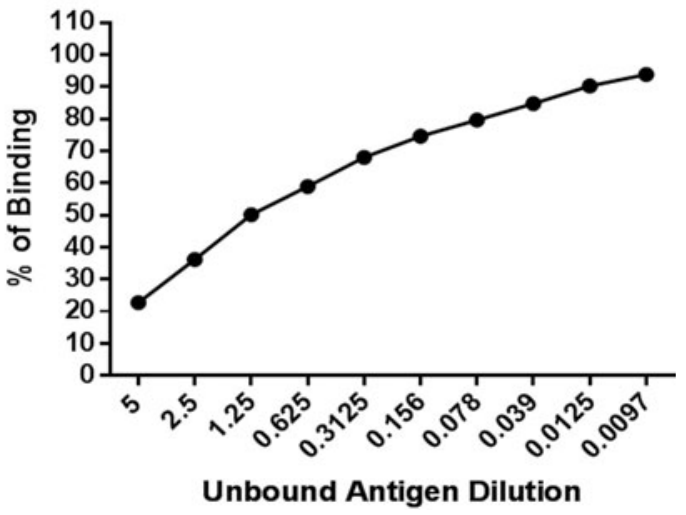

FIG. 1. (continued).

and $\mathrm{C} 7$ to be of IgG1 isotype, whereas C8 was IgG2a. In addition, immunoblot analysis of all 4 antibodies revealed binding of the mAbs also to denatured/linear hTNF $\alpha$. The experiment was carried out using two concentrations of hTNF $\alpha$ (100 and $500 \mathrm{ng})$. mAbs are capable of detecting $500 \mathrm{ng}$ of denatured $\mathrm{hTNF} \alpha$ and a faint band was detected at the lower concentration (Supplementary Fig. S2A).

\section{mAb C8 protects cells from TNF $\alpha$-mediated toxicity}

Several studies have shown that TNF $\alpha$ induces cell death in L929 cells through binding to TNF $\alpha \mathrm{R}^{(16)}$ To determine the activity of our purified recombinant hTNF $\alpha$ protein, L929 cells were subjected to different concentrations of hTNF $\alpha$, and at 48 hours posttreatment, the cell viability was examined using MTT assay. A concentration-dependent cell toxicity was observed and the $\mathrm{IC}_{50}$ (concentration at which there was $50 \%$ cell death) was determined to be $6.25 \mathrm{ng} / \mathrm{mL}$ (Fig. 2A). To confirm that the toxicity seen in L929 cells was indeed because of TNF $\alpha$, cells were challenged with heat-inactivated $\mathrm{hTNF} \alpha$ protein which had no effect on the cell viability (data not shown).

After establishing that recombinant $h \mathrm{TNF} \alpha$ was active, the ability of purified anti-TNF $\alpha$ mAbs to rescue cells from $\mathrm{TNF} \alpha$-mediated cytotoxicity was carried out. All 4 mAbs (C1, C2, C7, and C8) rescued L929 cells (Fig. 2B), and as can be seen from Figures $2 \mathrm{C}$ and D and Supple- mentary Fig. S2B,C the rescue was dose dependent. Of interest was the mAb C8, which rescued $50 \%$ of the cells from $\mathrm{hTNF} \alpha$-triggered cytotoxicity at $0.07 \mu \mathrm{g} / \mathrm{mL}$ and exhibited significant rescue even at $0.017 \mu \mathrm{g} / \mathrm{mL}$ (Fig. 2D).

\section{Comparison of $m A b C 8$ and infliximab (anti-TNF $\alpha$ mAb)}

Infliximab is a chimeric mAb developed against $\mathrm{TNF} \alpha$ and approved by the U.S. Food and Drug Administration (FDA) for the treatment of autoimmune disease. ${ }^{(17)}$ To compare mAb C8 and infliximab, indirect ELISA was carried out to study the binding of the mAbs to different concentrations of hTNF $\alpha$ antigen (Fig. 3A). The result revealed that not only in antigen dilution but also in antibody dilution assay, binding of $\mathrm{C} 8$ to $\mathrm{TNF} \alpha$ is highly comparable with that of infliximab. Both mAbs were found to have high titer as determined by the dilution curves (Supplementary Fig. S2D). Moreover, the binding affinity of the mAbs to immobilized $\mathrm{hTNF} \alpha$ was measured using the chaotrope ammonium thiocyanate ELISA to determine relative affinities of mAbs. As presented in Figure 3B, data demonstrate that the affinity of C8 and infliximab are very similar. Importantly, even the L929 cell assay showed that $\mathrm{TNF} \alpha$-mediated cytotoxicity could be rescued by $\mathrm{mAb} \mathrm{C} 8$ as efficiently as infliximab (Fig. 3C). 


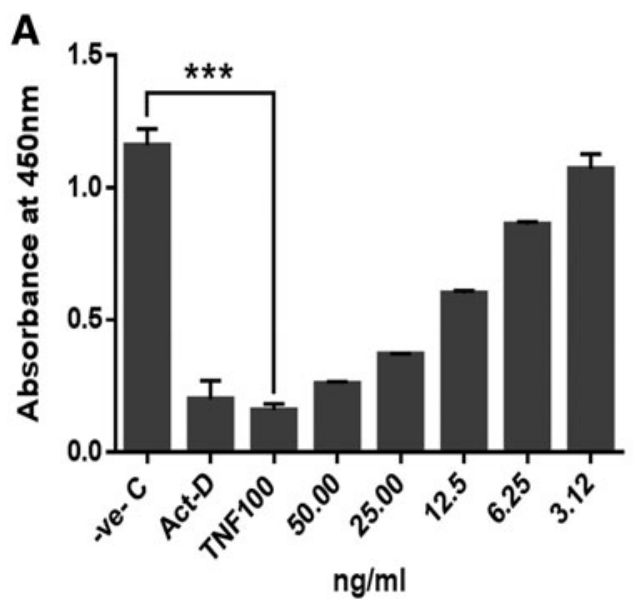

B
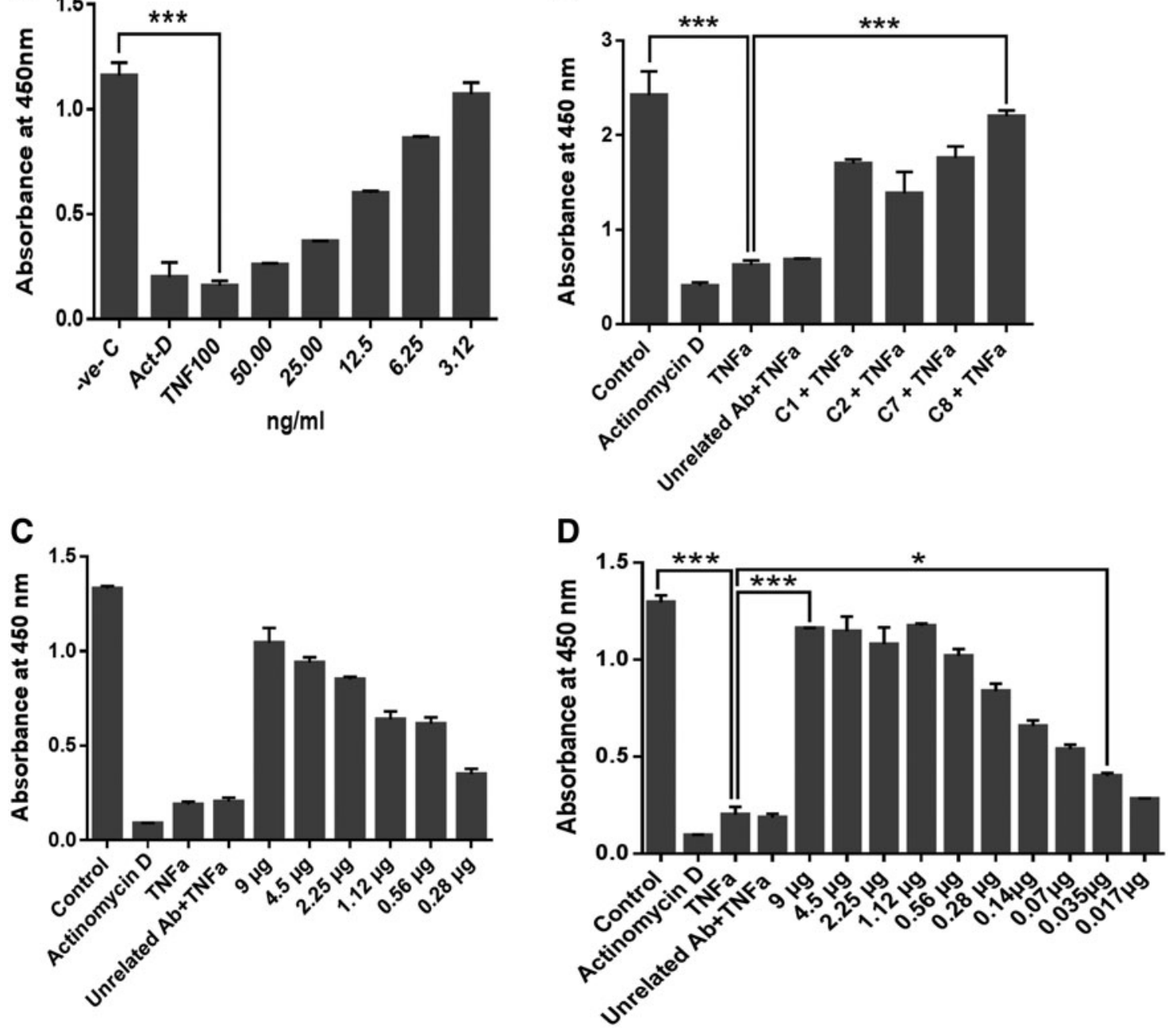

FIG. 2. (A) Assessment of human-TNF $\alpha$ activity by MTT assay. L929 cells were incubated with different concentrations of hTNF $\alpha$. After 48 hours of incubation, MTT was added and further incubated for 4 hours. Formazan crystals formed were dissolved in DMSO and optical density measured at $570 \mathrm{~nm}$. Acd was used as a positive control. (B) Rescue from TNFmediated toxicity with mAbs. L929 cells were incubated with $10 \mathrm{ng} / \mathrm{mL}$ hTNF $\alpha$ protein along with anti-TNF $\alpha$ purified antibodies at 100-fold molar excess. MTT assay was performed for cell viability analysis after 48 hours incubation. (C, D) Rescue of cells from TNF-mediated cell death by mAbs. L929 cells were treated with $10 \mathrm{ng} / \mathrm{mL}$ hTNF $\alpha$ protein along with the indicated different concentrations of anti-TNF $\alpha$ antibodies starting from $9 \mu \mathrm{g}$, which is 100 -fold molar excess. MTT assay was performed for cell viability analysis after 48 hours of incubation. C and D showed mAbs C1 and C8 dosedependent rescue assay, respectively. $n=3$ independent experiments, ${ }^{*} p<0.05$, $* * * p<0.001$. Acd, actinomycin-D; MTT, 3(4, 5-dimethylthiazol-2-yl)-2, 5-diphenyltetrazolium bromide.

\section{Effect of $m A b$ C8 on TNF $\alpha$-induced signaling}

TNF $\alpha$-mediated cell death has been shown through activation of JNK. ${ }^{(18)} \mathrm{TNF} \alpha$ triggers rapid phosphorylation of JNK and sustained JNK activation leads to cell death. ${ }^{(19)}$ To confirm this, L929 cells were treated with different concentrations of TNF $\alpha$ and JNK phosphorylation was assessed with western blotting. The result shows increase in JNK phosphorylation in a dose-dependent manner in $\mathrm{TNF} \alpha$-treated cells, whereas heat-inactivated $\mathrm{TNF} \alpha$ failed to show this (Fig. 4A). To test whether mAb C8 can inhibit TNF $\alpha$ mediated JNK activation, we exposed L929 cells with TNF $\alpha$ incubated with $\mathrm{C} 8$ or infliximab or $\mathrm{mAb} \mathrm{C} 12$, following which pJNK level was assessed. As the immunoblot analysis suggests, although mAb $\mathrm{C} 12$ had no effect, mAbs $\mathrm{C} 8$ and infliximab inhibited $\mathrm{TNF} \alpha$-mediated JNK phosphorylation.
Interestingly, mAb C8-treated cells showed better inhibition as compared with the infliximab-treated cells (Fig. 4B).

\section{Localization of $m A b C 8$ core epitope}

Identification and characterization of the binding sites of neutralizing antibodies might help in the development of new vaccine, diagnostics, and therapeutics. ${ }^{(20)}$ Epitope mapping provides insights into the therapeutic mechanism of an individual mAb. ${ }^{(21)}$ To identify the epitope corresponding to $\mathrm{mAb} \mathrm{C} 8$, we made three overlapping truncated hTNF $\alpha$ fragments F1, F2, and F3 as GST-fusion proteins. mAb C8 bound to full-length hTNF $\alpha$ (His-tag fusion $17 \mathrm{kDa}$ ) and hTNF $\alpha$ fragment 2 (26-131 aa) proteins, but not to F1 (1-53 aa) and F3 (96-157 aa) (Fig. 5A). The result was supported by indirect ELISA using different concentrations of the 

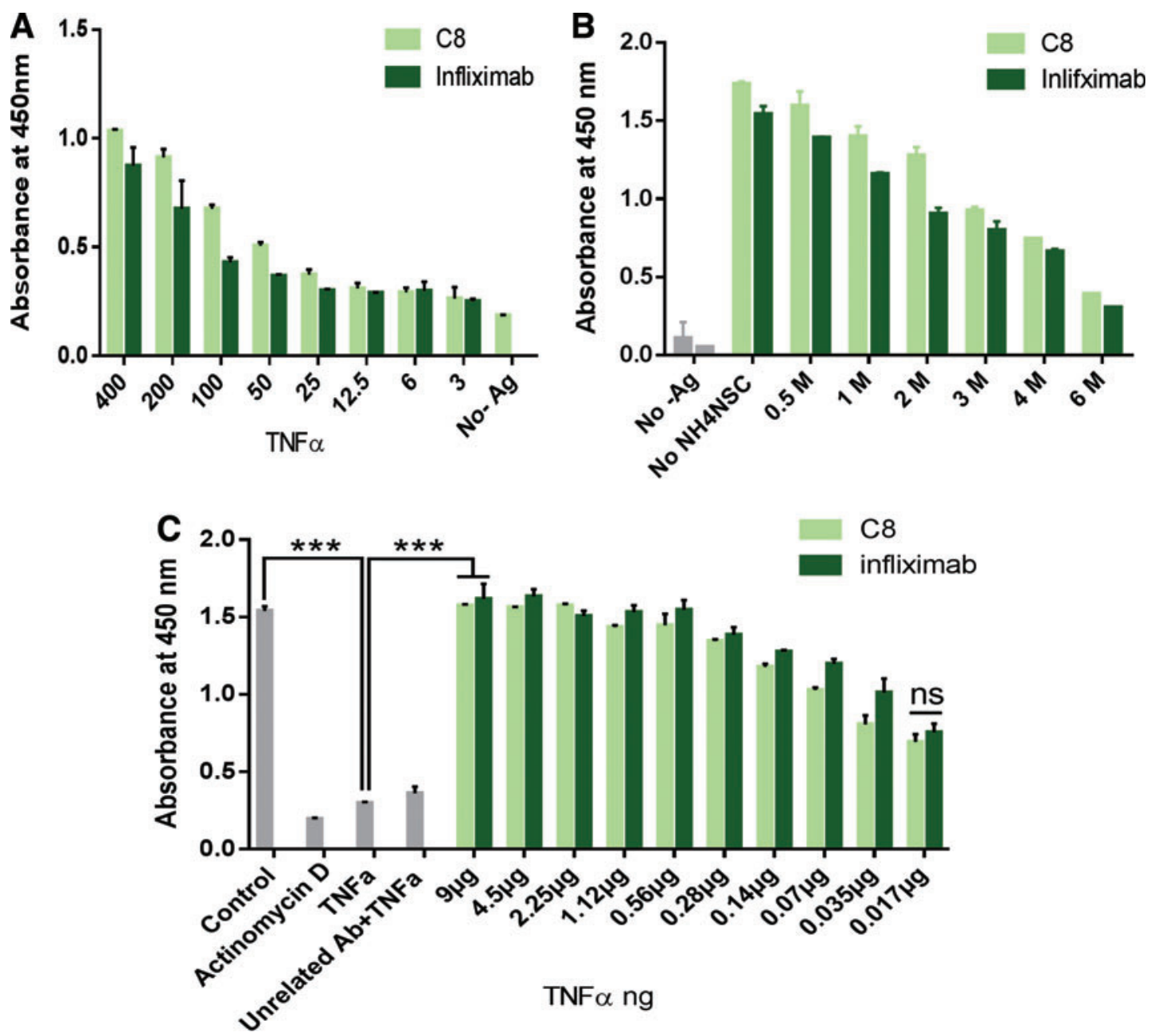

FIG. 3. (A) Comparison of antibody affinity. Different concentrations of hTNF $\alpha$ was coated (x-axis) on ELISA plate, followed by 2 hours of incubation of mAbs with $\mathrm{C} 8$ or infliximab. The binding of the antibodies was measured by incubation with the secondary antibody conjugated to HRP, followed by incubation with the substrate, $\mathrm{TMB}^{\mathrm{H}} \mathrm{H}_{2} . \mathrm{The}$ reaction was stopped with $\mathrm{H}_{2} \mathrm{SO}_{4}$ and the absorbance was measured at $450 \mathrm{~nm}$ using an ELISA microplate reader. Light green: $\mathrm{mAb} \mathrm{C} 8$; dark green: infliximab. (B) Comparison of antibody affinity using ammonium thiocyanate. Five hundred nanograms of hTNF $\alpha$ was coated in an ELISA plate followed by 2 hours of incubation with mAbs, followed by incubation with different concentrations of $\mathrm{NH}_{4} \mathrm{SCN}$ in $0.1 \mathrm{M}$ sodium phosphate buffer at $\mathrm{pH} 6.0$ for 15 minutes and then secondary antibody conjugated to HRP. (C) Rescue of cells from TNF $\alpha$-mediated cytotoxicity. L929 cells were treated with $10 \mathrm{ng} / \mathrm{mL}$ $\mathrm{hTNF} \alpha$ along with the indicated concentrations of mAb C8 or infliximab. MTT assay was performed to measure cell viability after 48 hours of incubation. Acd used as a positive control. *** $p<0.001$. mAb, monoclonal antibody; ns, nonsignificant.
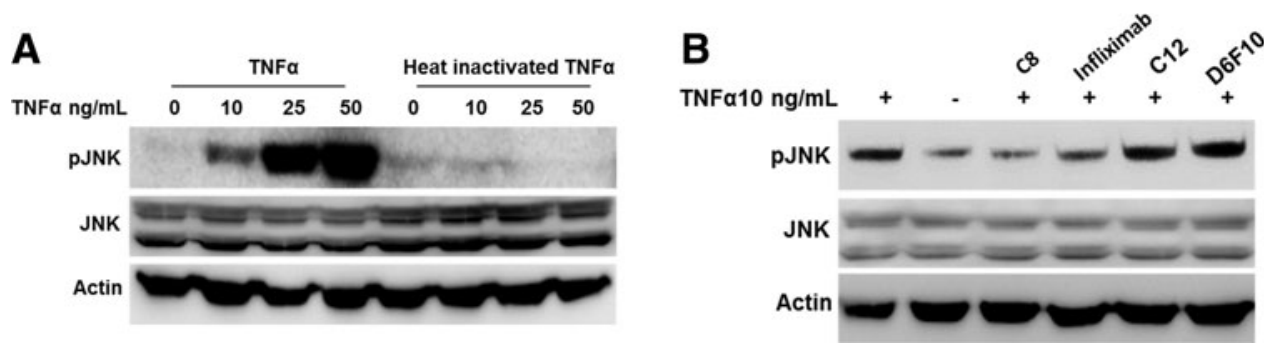

FIG. 4. Immunoblot analysis of TNF $\alpha$-induced JNK phosphorylation. L929 cells were treated with TNF $\alpha$ alone or along with antibodies for 15 minutes, followed by cell lysis. Cell lysates were electrophoresed on a 10\% polyacrylamide gel under denaturing and reducing conditions. Proteins were transferred from the gel to nitrocellulose membrane, probed with pJNK, JNK, and actin antibodies, followed by incubation with secondary antibody/HRP conjugate and visualized with ECL Kit (A) Cells were incubated with different concentrations of $\mathrm{TNF} \alpha$ as active and heat-inactive forms. (B) Cells were preincubated with $10 \mathrm{ng} / \mathrm{mL} \mathrm{TNF} \alpha$ along with mAbs C8/Infliximab/C12 or D6F10. JNK, c-Jun N-terminal kinase. 
A
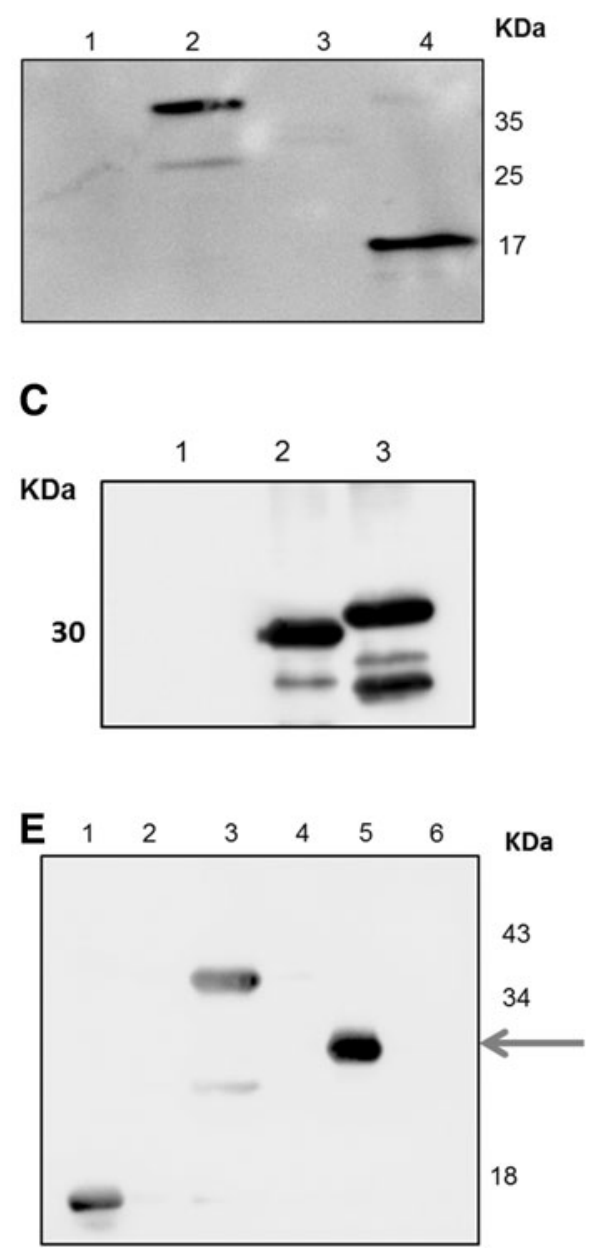

B

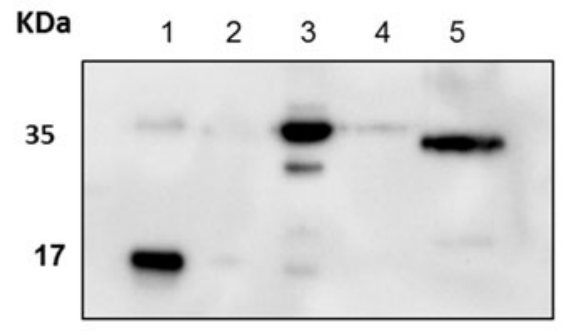

D

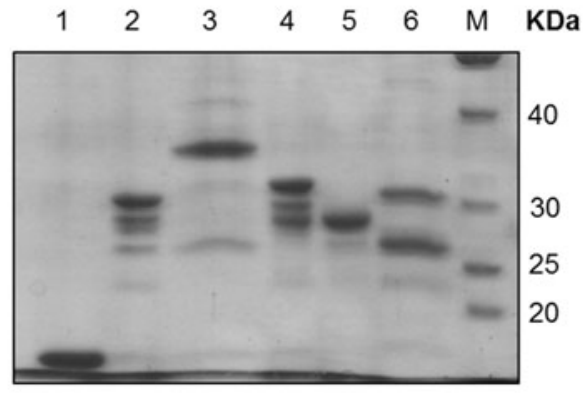

$\mathbf{F}$

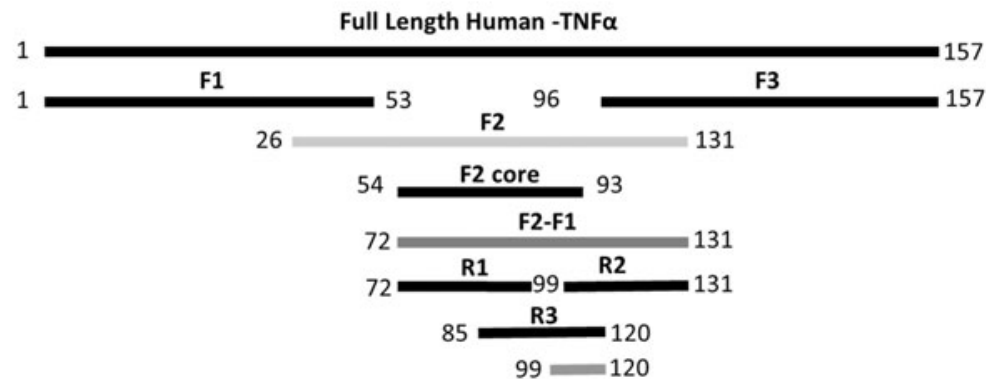

FIG. 5. (A) Immunoblot analysis by ECL of the truncated protein fragments with $\mathrm{mAb} C 8$; fragment1 (1-53), fragment2 (26-131), fragment 3 (96-157), and full-length hTNF $\alpha$. One microgram of each purified protein was electrophoresed on a $12.5 \%$ polyacrylamide gel under denaturing condition. Proteins were transferred to nitrocellulose membrane, probed with mAb C8, and developed using the ECL Kit (Millipore). Lanes: 1: fragment 1; 2: fragment 2; 3: fragment 3; 4: full-length hTNF $\alpha$. (B) Immunoblot analysis of the truncated protein fragments; full-length hTNF $\alpha$, F1, F2, F2 core region (54-93), and F2-F1 (72-131). Lanes: 1: full-length hTNFa; 2: F1; 3: F2; 4: F2 core region; 5: F1 and F2. (C) Immunoblot analysis of truncated protein fragments; R1 (72-107), R2 (99-131), and R3 (85-120) with mAb C8. The induced samples were electrophoresed on polyacrylamide gel and transferred to nitrocellulose membrane, probed with mAb C8 anti-TNF $\alpha$ antibody, and developed. Lanes: 1: R1; 2: R2; 3: R3. (D) Coomassie-stained gel showing purified hTNF $\alpha$ protein and truncated fragments. Lanes: 1: full-length hTNF $\alpha$; 2: F1; 3: F2; 4: F3; 5: 99-120 WT; 6: 99-120 QRE/PKD; M: molecular weight markers. (E) Epitope localization of $\mathrm{mAb} \mathrm{C} 8$. Immunoblot analysis of full-length hTNF $\alpha$ and truncated protein fragments; fragment1, fragment2, fragment 3, 99-120 WT, and 99-120 QRE/PKD mutants. Lanes: 1: full-length hTNF $\alpha ; 2$ : fragment 1; 3: fragment 2; 4: fragment 3; 5: 99-120 WT; and 6: 99-120 QRE/PKD (full-length hTNF $\alpha$ is His-fused protein; all truncated and mutated fragments are GST-fused). The arrow indicates that triple mutation QRE to PKD abrogated the binding of antibody to TNF $\alpha$. It determines the antibody core epitope is QRE. (F) Schematic representation of hTNF $\alpha$ constructs F1, F2, F3, F2-F1, core F2, R1, R2, R3, and 99-120. Truncated gene fragments were generated, cloned in pGEX5X2 vector, and expressed Escherichia coli BL21 (DE3) competent cells. GST, glutathione S-transferase; PKD, proline, lysine, aspartic acid; QRE, glutamine, arginine, glutamic acid; WT, wild type.

fragments incubated with mAb C8 (Supplementary Fig. S3A, B). The data suggest that the epitope of $\mathrm{mAb} C 8$ lies in $\mathrm{TNF} \alpha$ fragment 2 region comprising of amino acid 26-131. Indeed F2 in solution phase bound and competed out the binding of mAb C8 to full-length hTNF $\alpha$ as well (Data not shown).

To narrow down the epitope corresponding to the $\mathrm{mAb} \mathrm{C} 8$ further, two truncated constructs were generated from the F2 region of hTNF $\alpha, F 2$ core region (54-93) excluding F1 and F3 overlap and F2-F1 (72-131). mAb bound to F2-F1 (72-
131) but not to F2 core region (54-93) (Fig. 5B). The immunoblot study was confirmed by ELISA result as well (Supplementary Fig. S3C).

Then, 3 overlap fragment constructs were generated from F2-F1 (72-131) region, corresponding to R1 (72-107), R2 (99-131), and R3 (85-120), as GST-fusion proteins. The antibody bound to R2 and R3 but not to R1 (Fig. 5C).

Based on $\mathrm{mAb} \mathrm{C} 8$ binding interaction with both $\mathrm{R} 2$ and $\mathrm{R} 3$, it is clear that the overlap region of $\mathrm{R} 2$ and $\mathrm{R} 3$ contained 
A

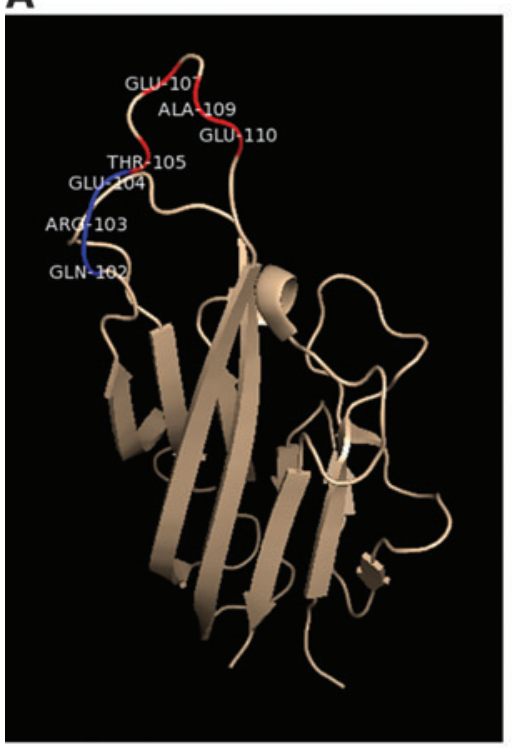

C

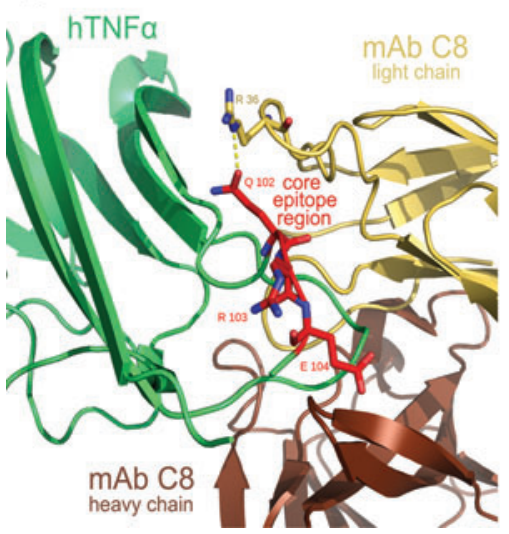

B

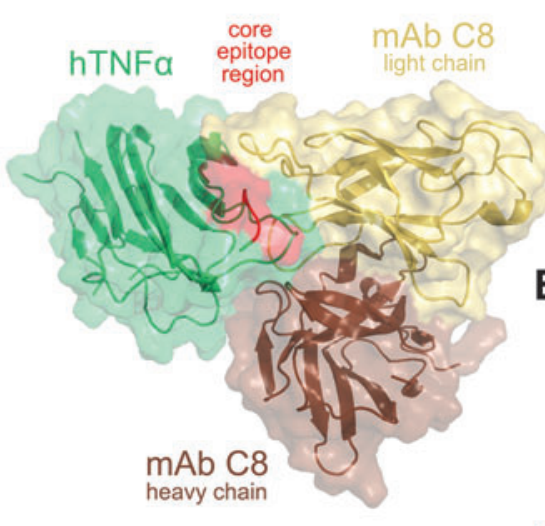

D

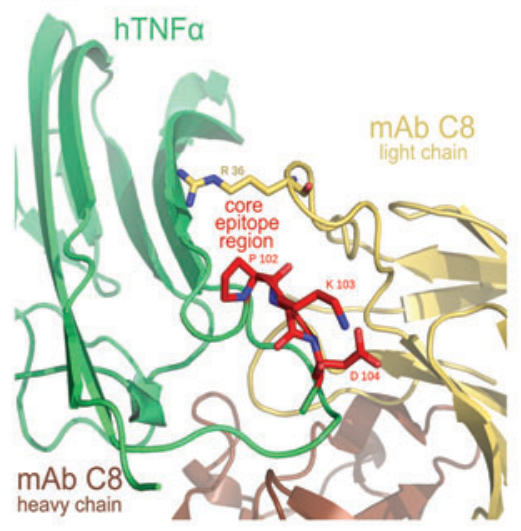

E

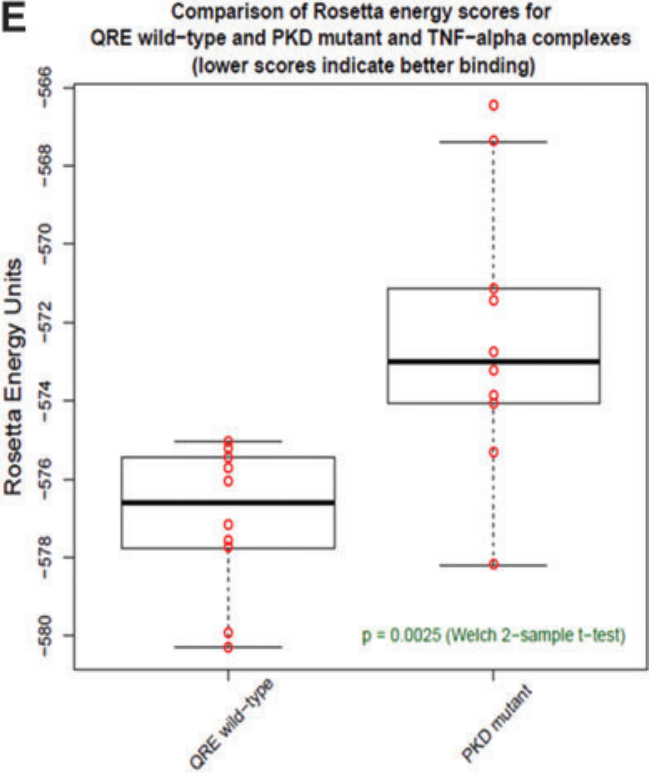

FIG. 6. (A) Ribbon diagram of hTNF $\alpha$ marking the epitopes corresponding to mAbs C8 and infliximab (in E-F loops of $\mathrm{TNF} \alpha$ ). Gln102, Arg103, and Glu104 indicated in blue for mAb C8 and Thr 105, Glu107, Ala 109, and Glu110 indicated in red for infliximab core epitopes. (B) Schematic representation of the epitope corresponding to mAb C8 in antigen/antibody complex. The core epitopic region (red) of mAb C8 is depicted on the surface of hTNF $\alpha$ (green), mAb C8 heavy and light chains depicted by brown and yellow, respectively. (C) Detailed hTNF $\alpha / \mathrm{C} 8 \mathrm{mAb}$ interface. C8 and hTNF $\alpha$ complex are presented as ribbon diagrams. The Q102 residue that are involved in the intermolecular interaction with R36 residue in light chain of antibody (epitopic region: red and blue; hTNF $\alpha$ : green; C8 heavy and light chains: brown and yellow, respectively). (D) Triple mutation introduced in epitopic region Q102R103E104 to PKD, disturbed C8 and hTNF $\alpha$ interaction. The images were generated using open-source PyMOL software. (E) Comparison of Rosetta energy scores for binding of WT (QRE) or mutated (PKD) hTNF $\alpha$ with mAb C8.

the core epitope of mAb C8, spanning amino acids 99-120 of hTNF $\alpha$. As observed in Supplementary Figure S2A, mAb C8 binding to hTNF $\alpha$ is specific and there is no crossreactivity of mAb C8 to mTNF $\alpha$. In the region $99-120$ of $h T N F \alpha$, four amino acids were found to be different between hTNF $\alpha$ and $\mathrm{mTNF} \alpha$. Therefore 3 residues in this stretch were mutated to the corresponding amino acids present in mTNF $\alpha,(\mathrm{Q} 102$ R103 E104 to PKD); both 99-120 WT and 99-120 triple mutants' protein constructs were generated. The binding of mAb C8 to 99-120 WT and 99-120 glutamine, arginine, glutamic acid (QRE)/PKD mutant proteins was analyzed. As shown in immunoblot Figure 5E and ELISA (Supplementary Fig. S3D), the mAb did not bind to the triple mutated fragment, thereby showing clearly that amino acids Q102 R103 E104 are crucial for the binding of $\mathrm{mAb} C 8$ to $\mathrm{hTNF} \alpha$.
A schematic diagram of truncated fragments is shown in Figure 5F.

Simulation studies revealed that, infliximab blocks TNF $\alpha$ activity due to binding to the E-F loop of the hTNF $\alpha$ structure, which hampers $\mathrm{TNF} \alpha$-receptor binding. Our study also showed that $\mathrm{mAb} \mathrm{C8}$ binds to the E-F loop in the vicinity of infliximab epitope. This suggests that the $\mathrm{C} 8$ binding to $\mathrm{TNF} \alpha$ being comparable with infliximab might be due to juxtaposed epitopes (Fig. 6A).

\section{Docking}

Docking study was performed by utilizing structural models based on confirmed sequences of the VH and VL chains of $\mathrm{mAb} \mathrm{C} 8$, which were generated from RNA isolated 
from hybridoma cells (Fig. 6B). The docking analysis revealed that glutamine at the 102 nd position of TNF $\alpha$ interacts with an arginine residue at the 36th position of the light chain of $\mathrm{mAb} \mathrm{C} 8$. This interaction is crucial to make antigen/antibody induced-fit correctly due to at least two reasons. First, Q102 to P mutation disrupted hydrogen bond between Q-102 (on TNF $\alpha$ ) and R-36 (on the antibody light chain). Second, the introduction of a proline slightly altered the conformation of the QRE loop, reducing the fit for multiple residues along the binding loop on TNF $\alpha$. This conformational change disturbed TNF $\alpha$ antibody binding (Fig. 6C, D). Finally, local docking was performed and Rosetta energy score differences were calculated for both WT TNF-Ab as well as mutated TNF-Ab complexes. The entire mutated TNF-Ab complex score is more unfavorable energetically than WT TNF-Ab complex, indicating a disruption in antibody recognition (Fig. 6E).

\section{Discussion}

$\mathrm{TNF} \alpha$ is one of the most important proinflammatory cytokines which regulates a number of cellular processes like cell proliferation, differentiation, and apoptosis. ${ }^{(22)}$ Excessive production of $\mathrm{TNF} \alpha$, however, is detrimental to health and needs to be regulated. Specific antibodies to TNF $\alpha$ have proven to be useful blockers of TNF $\alpha$-mediated toxicity. As it is known, anti-TNF $\alpha$ agents bound to TNF $\alpha$ may block interaction between TNF $\alpha$ and its receptors, thus, basically inhibit $\mathrm{TNF} \alpha$-mediated proinflammatory signal activation. ${ }^{(23,24)}$

Even though there are a number of anti-TNF $\alpha$ agents in the market, there is a demand for more $\mathrm{TNF} \alpha$-specific antibodies. Like infliximab, Adalimumab, and Etanercept are currently being used in the alleviation of inflammatory immune disorders through interruption of TNF $\alpha / \mathrm{TNFR}$ interaction. ${ }^{(25)}$ Infliximab was the first approved anti-TNF $\alpha$ drug for the management of autoimmune conditions, such as Crohn's disease, rheumatoid arthritis, ankylosing spondylitis, psoriatic arthritis, and various inflammatory skin problems. ${ }^{26,27)}$

In our study, we found $\mathrm{mAb} \mathrm{C} 8$ to bind with high affinity to TNF $\alpha$. Since hTNF $\alpha$-mediated cell death in L929 fibroblast cells is a well-accepted cell culture model,${ }^{(16)}$ we utilized it to test the rescue from cytotoxicity by our panel of mAbs. mAb C8 inhibited TNF $\alpha$-mediated activity significantly and comparable with that of infliximab. Due to specificity of $\mathrm{mAb}$ $\mathrm{C} 8$ to human-TNF $\alpha$ only, we could not test the effect of $\mathrm{mAb}$ $\mathrm{C} 8$ in blocking the biological activity of TNF $\alpha$ in a mouse model. However, comparable cell rescue from $\mathrm{TNF} \alpha-$ mediated toxicity and inhibition of TNF $\alpha$-mediated signaling by both antibodies may suggest the capability of $\mathrm{mAb} C 8$ in blocking the physiological activity of $\mathrm{TNF} \alpha$ also in-vivo. That $\mathrm{mAb}$ C8 inhibits $\mathrm{TNF} \alpha$-induced cell signaling was also demonstrated by assessing the decrease in activation of JNK.

To get insights into the mechanism by which $\mathrm{C} 8$ antibody inhibits hTNF $\alpha$-mediated toxicity, we initiated studies to identify the epitope corresponding to the mAb. The core epitope of $\mathrm{mAb} \mathrm{C8}$ was delineated to amino acid sequence 99-120. Mutational analysis in this region established unequivocally that residues Gln102, Arg103, and Glu104 are the most critical for binding of $\mathrm{mAb} C 8$ to hTNF $\alpha$. It is worth mentioning that, these residues are located in the E-F loop of $\mathrm{TNF} \alpha$ structure. Interestingly, the epitope of infliximab on
$\mathrm{TNF} \alpha$ structure comprises of the C-D and E-F loop and include residues Glu67-His73 and Thr105-Lys112, respectively, as well as several residues in C and D strands and blocks its activity. $\mathrm{mAb} \mathrm{C} 8$ and infliximab binding to the $\mathrm{E}-\mathrm{F}$ loop hampers TNF $\alpha$ binding to its receptor, as a result inhibits its activity.

In conclusion, we have established a mAb with the ability to neutralize $h \mathrm{TNF} \alpha$ at the same efficiency as infliximab, therefore could be explored for clinical application.

\section{Acknowledgments}

The authors thank the Central Animal Facility, Indian Institute of Science (IISc). They thank Dr. Manjula Das and Dr. Akanksha Dixit for valuable discussions and critical comments. They greatly acknowledge financial support from the Department of Biotechnology, DBT-IISc partnership program. They also thank IISc-student fellowship support.

\section{Author Disclosure Statement}

No competing financial interests exist.

\section{Supplementary Material}

Supplementary Figure S1

Supplementary Figure S2

Supplementary Figure S3

\section{References}

1. Tracey KJ, and Cerami A: Tumor necrosis factor: A pleiotropic cytokine and therapeutic target. Ann Rev Med 1994;45:491-503.

2. Baxter GT, Kuo RC, Jupp OJ, Vandenabeele P, and MacEwan DJ: Tumor necrosis factor-alpha mediates both apoptotic cell death and cell proliferation in a human hematopoietic cell line dependent on mitotic activity and receptor subtype expression. J Biol Chem 1999;274:9539-9547.

3. Clark IA, Virelizier JL, Carswell EA, and Wood PR: Possible importance of macrophage-derived mediators in acute malaria. Infecti Immun 1981;32:1058-1066.

4. van der Bruggen T, Nijenhuis S, van Raaij E, Verhoef J, and van Asbeck BS: Lipopolysaccharide-induced tumor necrosis factor alpha production by human monocytes involves the raf-1/MEK1-MEK2/ERK1-ERK2 pathway. Infect Immun 1999;67:3824-3829.

5. Kircheis R, Milleck J, Korobko VG, Shingarova LN, and Schmidt HE: Differences in the biological activity of TNF alpha and TNF beta correlate with their different abilities for binding to the target cells. Eur Cytokine Netw 1992;3: 381-390.

6. Loetscher H, Pan YC, Lahm HW, Gentz R, Brockhaus M, Tabuchi H, and Lesslauer W: Molecular cloning and expression of the human $55 \mathrm{kd}$ tumor necrosis factor receptor. Cell 1990;61:351-359.

7. Tartaglia LA, and Goeddel DV: Two TNF receptors. Immunol Today 1992;13:151-153.

8. Aggarwal BB, Gupta SC, and Kim JH: Historical perspectives on tumor necrosis factor and its superfamily: 25 years later, a golden journey. Blood 2012;119:651-665.

9. MacEwan DJ: TNF receptor subtype signalling: Differences and cellular consequences. Cell Signal 2002;14:477-492. 
10. Peyrin-Biroulet L: Anti-TNF therapy in inflammatory bowel diseases: A huge review. Minerva Gastroenterol Dietol 2010;56:233-243.

11. $\mathrm{Ma} \mathrm{X}$, and $\mathrm{Xu} \mathrm{S}$ : TNF inhibitor therapy for rheumatoid arthritis. Biomed Rep 2013;1:177-184.

12. Ho SN, Hunt HD, Horton RM, Pullen JK, and Pease LR: Site-directed mutagenesis by overlap extension using the polymerase chain reaction. Gene 1989;77:51-59.

13. Schwede T, Kopp J, Guex N, and Peitsch MC: SWISSMODEL: An automated protein homology-modeling server. Nucleic Acids Res 2003;31:3381-3385.

14. Konagurthu AS, Whisstock JC, Stuckey PJ, and Lesk AM: MUSTANG: A multiple structural alignment algorithm. Proteins 2006;64:559-574.

15. Gray JJ, Moughon S, Wang C, Schueler-Furman O, Kuhlman B, Rohl CA, and Baker D: Protein-protein docking with simultaneous optimization of rigid-body displacement and side-chain conformations. J Mol Biol 2003;331:281-299.

16. Humphreys DT, and Wilson MR: Modes of L929 cell death induced by TNF-alpha and other cytotoxic agents. Cytokine 1999;11:773-782.

17. Monaco C, Nanchahal J, Taylor P, and Feldmann M: AntiTNF therapy: Past, present and future. Int Immunol 2015; 27:55-62.

18. Dietrich N, Thastrup J, Holmberg C, Gyrd-Hansen M, Fehrenbacher N, Lademann U, Lerdrup M, Herdegen T, Jaattela M, and Kallunki T: JNK2 mediates TNF-induced cell death in mouse embryonic fibroblasts via regulation of both caspase and cathepsin protease pathways. Cell Death Differ 2004;11:301-313.

19. Barbin G, Roisin MP, and Zalc B: Tumor necrosis factor alpha activates the phosphorylation of ERK, SAPK/JNK, and P38 kinase in primary cultures of neurons. Neurochem Res 2001;26:107-112.

20. Gershoni JM, Roitburd-Berman A, Siman-Tov DD, Tarnovitski Freund N, and Weiss Y: Epitope mapping: The first step in developing epitope-based vaccines. BioDrugs 2007;21:145-156.

21. Hasan SS, Miller A, Sapparapu G, Fernandez E, Klose T, Long F, Fokine A, Porta JC, Jiang W, Diamond MS, Crowe JE Jr, Kuhn RJ, and Rossmann MG: A human antibody against Zika virus crosslinks the $\mathrm{E}$ protein to prevent infection. Nat Commun 2017;8:14722.

22. Liu ZG: Molecular mechanism of TNF signaling and beyond. Cell Res 2005;15:24-27.

23. Wong M, Ziring D, Korin Y, Desai S, Kim S, Lin J, Gjertson D, Braun J, Reed E, and Singh RR: TNFalpha blockade in human diseases: Mechanisms and future directions. Clin Immunol 2008;126:121-136.

24. Sedger LM, and McDermott MF: TNF and TNF-receptors: From mediators of cell death and inflammation to therapeutic giants-Past, present and future. Cytokine Growth Factor Rev 2014;25:453-472.

25. Mukai Y, Nakamura T, Yoshikawa M, Yoshioka Y, Tsunoda S, Nakagawa S, Yamagata Y, and Tsutsumi Y: Solution of the structure of the TNF-TNFR2 complex. Sci Signal 2010;3:ra83.

26. Buch MH, Conaghan PG, Quinn MA, Bingham SJ, Veale D, and Emery P: True infliximab resistance in rheumatoid arthritis: A role for lymphotoxin alpha? Ann Rheum Dis 2004;63:1344-11346.

27. Liang S, Dai J, Hou S, Su L, Zhang D, Guo H, Hu S, Wang H, Rao Z, Guo Y, and Lou Z: Structural basis for treating tumor necrosis factor alpha (TNFalpha)-associated diseases with the therapeutic antibody infliximab. J Biol Chem 2013;288:13799-13807.

Address correspondence to: Anjali A. Karande $\mathrm{Lab}$ \# FB-05

Division of Biological Sciences

Department of Biochemistry Indian Institute of Science (IISc) Bengaluru 560012 Karnataka India E-mail: anjali@iisc.ac.in

Received: March 26, 2019 Accepted: June 4, 2019 